\title{
THE ROLE OF SHALIHAH WOMEN IN TURNING OUT RABBANI GENERATION IN THE FAMILY ENVIRONMENT \\ Asrori \\ asrori@fai.um-surabaya.ac.id
}

\begin{abstract}
This study aims to explore how the role of shalihah (pious) women in turning out rabbani generation in a family environment. The study was a qualitative research with library study type by using the method of documentation and observation. The results of this study were concluded: First: There are two characteristics divisions of shalihah women namely: to obey Allah and to obey the husband. Second, the tips in turning out rabbani generation are among: Get used children to do good things, Lead children to the personality of Rasululloh SAW as a role model, Perform Good Exemplary, Pray for the children and Do not curse them, Fill their spare time with useful things, Look for the right time to give instructions, Tell the stories to install the values and virtues for the children. Third, the role of shalihah (pious) women in turning rabbani generation in the family is: women as servants of God, women as mothers and women as role models in their communities.
\end{abstract}

Keywords: Shalihah Women, Rabbani Generation, Family Environment

\section{A. INTRODUCTION}

Basically, human beings were created by God in a state of fitrah (natural tendencies), then his parents decorate the man, whether to be a good human being remains in Islam or he becomes a bad man even out of Islam,

Prophet Muhammad shallahu 'alaihi wa sallam said: "Every child is born in a state of nature. Both his parents make him a Jew, a Christian or a Zoroastrian ".

Imam al-Ghazali said: "Child is mandated by the hands of his parents. Sacred heart is a pearl that is still raw, not yet carved out and shaped. This pearl can be carved in any form, easily inclined to everything. If he is socialized and taught with kindness, then he will grow in goodness. The impact, both parents will live happily in the world and the hereafter. Everyone can become teacher and educator. However, when he is familiarized with evil and being forgotten - like neglected animals - child will be wretched and perish. His sin will be wrapped around the neck of people who should be responsible for him and be his guardian ".

So, it is true that the basic rules proclaimed by Rasululloh saw in the Hadits above is that a child growing up in accordance with both parents. Both of them give the enormous influence in the child's life. ${ }^{1}$

Verily Allah has ordered both parents to educate their children and give this responsibility to them both in His words: "O you who believe, protect yourselves and your families from a fire whose fuel is men and stones, the guardian is rough and hard angels, who

1 Nur Muhammad Abdul Hafiz Suwaid, Prophetic Parenting How to Educate Children Prophet,

(Yogyakarta: Pro-U Media, 2010), 47-51. 
do not disobey Allah in what was ordered ".2.

Ali bin Abi Talib ra interpretted the verse, he said: "Teach yourself and your family a favor".

And, it cannot be denied that a mother has the greatest role in turning out a pious (shalih) generation, so that Islam ordered him to attempt to marry a woman who sholihah (pious), because it will affect the children's education and prepare the rabbani generation.

It is fitted what the wise man said: "Mother is a school that is when you prepare him, you have to prepare a nation with a good foundation. ${ }^{3}$ Mother is the first cleric, before the children studied to some great religious teachers. So, intelligence, tenacity and temperament of the mother are the dominant factors for the future of children, including the mother's milk.

We see the fact that behind the great man, there must be a great woman. There is a great mother behind a great man. If there is a man who became scholars, famous figures, or knight hero, look at their mother because the mother has a major role in shaping the personality, characteristic and knowledge. We look at the greatness of the previous clericals, for example Urwah bin Zubair, Hasan alBashri, Rabi'ah ar-Ra'yi, Imam Syafi'i, they are great scholars in their knowledge, memorizing al-Quran, toughness. They do not suddenly become ulama' (scholars), be great for granted, but there is the role and education of a great mother behind them.

Therefore, the author was interested in writing about "the role of

\footnotetext{
${ }^{2}$ Qs. at-Tahrim: 6

${ }^{3}$ Abdullah Nasih Ulwan, Child Education inIslam,(Jakarta: Pustaka Amani, 2002), 9
}

sholihah women in turning out rabbani generation in a family environment".

\section{B. METHODS}

The analysis used in this study was a non-statistical data analysis. The data analysis is one step of a study. Data analysis was performed when and after a set of facts or information obtained through some data collection techniques. According to Bogdan and Taylor, data analysis is the process of detailing the formal effort to find a theme and formulate a working hypothesis (idea) as suggested by the data and in an effort to provide assistance to the themes and hypotheses. ${ }^{4}$

This type of research used in the study "The role of shalihah women in turning out Rabbani generation in a family environment" was literature research or literature approach; the data collection method was the method of documentation and observation method, while the method of interview was as a method of investigation to collect data relating to research in this thesis. Analysis of the data used in this study was a non-statistical analysis.

The purpose of this study was to determine how far the role of shalihah women in turning out rabbani generation in a family environment, which is expected to appear Muslim women who took part in taking a large part of the order will be born rabbani generations who led this people and strive to uphold the sentence of God on this earth.

\section{DISCUSSION OF RESULTS}

1. The essence of Shalihah Women

a. Understanding Shalihah Women Shalih etymologically is derived from the Arabic word "sholuha

\footnotetext{
${ }^{4}$ Moleong, methodology, 280.
} 
yashluhu sholaahan" means "good", "not broken" and "worth". "While Shalih or shalihah is isim fa'il (noun as doer) of the word mentioned above which means people are good, people are not broken and people are worth.

While the Qur'an says Shalih is always coupled with faith, as in the surah al-Baqarah verse 82, an-Nisa verse 124, An-Nahl verse 97 or an-Nur verse 55 and many in other surah. One of them is the word of God: "He who does good deeds, whether male or female in a state of faith, then indeed we will give him a good life and indeed we will give a reply to them with a better reward than what they have doing". 6

Ibn Katsir said that who do charitable deeds means that follow the book of Almighty Allah (al-Qur'an) and the Sunnah of His Prophet, Muhammad, both men and women whose hearts believe in Allah and His Messenger. So God promised them a good life in the world and will reward in the hereafter with a good response from the charity. The good life includes tranquillity, as they may be. ${ }^{7}$

From the interpretation above, it can be concluded that the meaning of the shalih in terminology is the believer in Allah and His Messenger, and to make a sincere (to follow Qur'an and Hadits). While, shalihah women means women who believe in Allah and His Messenger, and follow Qur'an and Hadits.

\footnotetext{
${ }^{5}$ Jumhuriyah Mishr al-Arabiyah, al-Mu'jam AlWasiith, (Cairo: Maktabah al -Syuruq ad-Daula, 2008), 539.

${ }^{6}$ Qs. An-Nahl: 97

7 Abul Fida 'Ibn Kathir, Tafsir Ibn Kathir,Jakarta: (Reader Imam Shafi'i, 2005), vol 2, 103 .
}

\section{b. Characteristics of Shalihah Women ${ }^{8}$}

The term Sholihah is the best of the nickname for women. Not random women have right to have the kind title. The title is only awarded to female role models, which have certain characteristics with high consequence.

These characteristics at least describe the implementation of Qur'an surah at-Taubah verse 24 , i.e. both in behavior and mindset the women use priority scale. The first priority is for the right of God, the second is for the Apostles, the next priority is for jihad (), and the mundane falls on the last order.

While, in Surah an-Nisa, the characteristics of Sholihah women are divided into two:

1). Obedience to God

2). Obedience to the husband

God said: "Because the Sholihah woman is the woman who is pious to Allah and keep herself when her husband was away (obey her husband) as Allah has been keeping herself"9

Sholihah women according to the verse above are women who obey Allah and women who obey the husband. But it need to be elaborated and detailed in two parts in order to clear the problem; first is about the general characteristics of shalihah women, then the following is about the characteristics of the woman who had married.

The distribution of the characteristics of women sholehah as follows:

a) To obey Allah and His prophets

Actually if the shalihah woman obey Allah and obey His Messenger, automatically shalihah woman definitely obey her husband, as well as

\footnotetext{
8 Abu Muhammad Rashid Rida, Women's Feature and Functionality Shalihah,(Solo: Pustaka Al-Alaq, 2000), 37

${ }^{9}$ Qs. An-Nisa ': 34
} 
to the other commands from Allah and His Messenger.

b) To obey the husband

This case is among of these; always making husband pleasant and affection towards children, keeping her own honor and her husband's property when her husband is not at home, not underestimating the husband's provision, not opening her husband disgrace and not finding any fault for the divorce, always nourishing herself, physical cleanliness and beauty as well as household cleanliness, helping her husband in maintaining the trust; and educating children as good as possible to become shalih shalihah children.

c. Examples of Shalihah Women Greatness

1) Mothers of worship experts: the fortitude of Imron's wife (Hannah binti Faqudz), Aisyah ummul mukminin (mother of the believers), and his brother, Asthma 'ra in instilling the love of God and Islam to the conqueror of the Barbarians, Abdullah bin Zubair, and the sacrifice of Sumayyah bint Khayyath at her honor for his son, Ammar bin Yasir.

2) Mothers of native scholars: AnNawar bint Malik and his son, Zaid bin Thabit, the Islam faraidh (the science of inheritance) in the time of Prophet SAW, mother of Rabi'ah Al-Ra'yi, the great scholar with a ratio of 30,000 dinars.

3) Mothers of the Mujahid who sacrificed their lives for Islam: Shafiyah bint Abdul Muttalib and his son, the defenders of the Prophet, Zubayr ibn al-Awam, Rubayyi bint al-Bara 'and his son; Haristah, Khonsa; mother of four syuhada' (martyrs) at the Battle of Qadisiyah.

\section{Studies of Rabbani Generation}

a. Definition of Rabbani

Allah says in the His glorious book: "It is natural for a human being that God gave him alKitab, wisdom and prophet hood, then he said to the man:" Be you be my worshipers, not worshipers of God", but he said: "you shall be those Rabbani, because always teach al-Kitab and caused you have studied it". ${ }^{10}$

Ibn Abbas, Abu Razin and other scholars in deciphering (You shall be those Rabbani), they say: "Be wise men, the scholars', and those who are patient". While Hasan and others said: "Be fuqaha (people who understand well about religion)". And also narrated from Hasan that the meaning is worship expert and taqwa (piety) expert. ${ }^{11}$

According to Ibn Zaid the meaning of this verse is "I did not invite you to worship me, but I called for you to be a leader, cleric with adhering to the rule of God and stay in obeying Him ".

The word "Rabbaniyyin" is the plural of Rabbani. A wise person would not encourage people (make a cult) he especially deify him, but encourage his people become rabbani generation because it teaches the book and constantly learn.

b. Tips Turning out Rabbani Generation

Get used children to do goodness, ${ }^{12}$ lead the children in the personality of Rasulullah saw as a

\footnotetext{
${ }^{10}$ Qs. Ali Imron: 79

11 Abul Fida 'Ibn Kathir, Tafsir Ibn Kathir,Jakarta: (Reader Imam Shafi'i, 2005), vol 2,80 .

${ }^{12}$ Muhammad Rashid Dimas, 25Kiat Affect Life and Mind of the Child, (Jakarta: Rabbani Press, 2005), 95.
} 
role model ${ }^{13}$, showing good exemplary ${ }^{14}$, pray for the children and do not curse them ${ }^{15}$, filling their free time with useful things ${ }^{16}$, look for the right time to give guidance $^{17}$, tell the story to instil some values and virtues on the children selves. ${ }^{18}$

c. Factors influencing the Formation of Rabbani Generation

Being shalih of parents, the scientific of parents, children living environment, school, communication media, and servant.

\section{Role of Shalihah Women in Turning out Rabbani Generation in Family Environment}

In the last few centuries, a Muslim woman is faced with the reality of jahiliyah (stupidity) that is very difficult to avoid. The existence as queen of household, torchbearers of peace in the family institution is gradually fading. Her job as the mother of her children, have often been ignored. Similarly, her role as a Muslim woman who devotes to the father and the mother or istiqomah (consistent) on faith, becomes very rare we encounter. That many of us encounter is an ignorant (jahiliyah) woman with all the luscious. This type of woman who became a top hit of the world, the principal topic of

\footnotetext{
${ }^{13}$ Ibid., 151.

14 Nur Muhammad Abdul Hafiz Suwaid, Prophetic Parenting How Prophet Educate Children,

(Yogyakarta: Pro-U Media, 2009), 139.

${ }^{15}$ Muhammad Rashid Dimas, 25Kiat Affect Life and Mind of the Child, (Jakarta: Rabbani Press, 2005), 167.

${ }^{16}$ Ibid., 185.

17 Muhammad Nur Abdul Hafiz Suwaid, Prophetic Parenting How the Prophet educating Children,

(Yogyakarta: Pro-U Media, 2009), 141.

18 Ibid., 166.
}

conversation, exposed by a variety of mass media, either through newspapers, radio, internet, television, films or slides. Until nicety ads like soap package does not miss to promote the female sexual excitement and flirtation. Consequently, it stimulates the splendour of moral decadence everywhere; Islam women are not also spared to be infected by similar pollution. They have admitted that it is appropriated when using halfnaked dress, transparent, rigorous, and jig-dancing in the public.

Gender equality much touted by the western has penetrated into the body of the Muslims. They have been deceived by the thought of the western, even some who follow these ideas. So, how exactly is the role of Islamic women in building a family? How should the shalihah women role in the turning out Rabbani generation in the family environment?

The family is the basic foundation to spread Islam. From the family, it emerges the leaders who strive in the way of Allah, and will come seedlings who will struggle to exalt Allah sentences. And the biggest role in it is women.

In principle, the role of shalihah women has much in similar to the obligations of husband responsibility. However, it can be done by women and based on the position and woman nature. Among Shalihah women's roles are:

\section{a. Women as the Servant of God}

The obligation for each of His servants on the Khaliq (creator) without exception (both male and female) is to worship Him, not to make alliances for Him with anything. He said: "It is I never created the jinn and mankind except to worship Me". ${ }^{19}$

${ }^{19}$ Qs. Ad-dzariyat: 56 
"Say! Indeed I am commanded to worship Allah by purifying obedience to Him in carrying Din ". ${ }^{20}$ "We did not send a prophet before you, but We revealed to him that there is no god but Me, ye Worship Me". ${ }^{21}$

The series of the verses above contain a basic principle of Islam that is the main purpose of human creation is to worship God alone and not associate him with anything. To simplify the obligations for the purpose can be fulfilled, Allah sent some prophets, instruction carriers in order to teach the ordinances of worship according to Allah willing and guidance.

Then the sense of worship itself is not as perceived by some, the worship is not only covering: the syahadat (creed), prayer, fasting Ramadan, zakat and hajj but worship it also includes human relationships; Muslims with Muslims (household, neighbors, society and the State), Muslims with non-Muslims, the human with the natural surroundings which are all integrally is set up well by Allah and His Messenger.

\section{b. Women as a mother}

Nothing greatest glory is given by God for a woman except her role to become a mother. Even the Messenger of Allah said when asked by someone: "O Messenger of Allah, who are the people most entitled to treat well?" He said: "Your mother". The man asked again: "Then who(m)?" The Prophet replied: 'Your mother'. The man asked again: "then who(m)?" Replied the prophet: "Your mother". "Then who(m)?" He asked again. "Then your father," he replied. ${ }^{22}$

\footnotetext{
${ }^{20}$ Qs. Az-Zumar: 11

${ }^{21}$ Qs. Al-Anbiya ': 25

${ }^{22}$ Bukhari and Muslim
}

"The shape of small alliances, but the most decisive in the community is an institution of the family or household. A society would be better if the occupant or the environment consists of the families in charge, otherwise will be damaged if the elements of the residents are dilapidated family. And it is impossible for a harmonious family institution without the harmony of its own members, the maximum should be a match between mother and father.

The role of shalihah women as a housewife is:

1) As a faithful companion of her husband

To Stare at her husband in the circumstances, to accompany him in the fun and joy, to cheer in grief and sorrow, to make delightful sorrow and anxiety husband are the wives obligations as companion of their husbands. If the wife can apply to him as to what described above, his love and affection grow more to her and satisfied with his wife services was natural if he received a reply in kind, as the Prophet said: "Every wife who died approved by him then he will go heaven".

Ibn Mas'ud ra from the Prophet, in fact he said: "If she washes her husband's clothes, then Allah will record the reward gained a thousand, thousand forgive sins, raise in rank a thousand levels and will be asked for mercy of everything exposed to the sun"

It should a shalihah wife, obey his husband's commands, listen carefully when husband talking, go delivered with a smile, and welcome back with intimacy. She is not also treasonous when her husband is not beside her, giving the husband a respect although it is just a little, honor 
the guests, friends and family of her husband and others. ${ }^{23}$

2) As the custodian of her children

Shalihah wife is certainly not going to waste or betray the mandate, namely the children of God entrusted to her. Because the mandate will be accountable for the parents in front of the fairest judge, Allah.

In this case, the mother responsibility is heavier to educate their children to be shalih, that is not to be victim suffering to the elderly even been instrument in the Hereafter later. Obligations are a mother on children, among others:

a) to keep the food

A mother let her keep the child's mouth from the food and drinks are not thoyyib (good) and not halal (kosher). Because it's affecting children's behavior of lazy worship, difficult to be educated by the karimah (good) morality, and easy to do evil and unlawful acts.

b) to maintain the children into adulthood

A shalihah mother would patiently care for the children had been born, take care of them, bathe them, feed them for two years and then wean, take care and keep of the things that are forbidden by Allah and His Messenger. And continue to educate the children till adult or married, with an education taught by the Prophet.

3) As Educator of the children

Every child born will be equipped with the potential (natural power) that can be directed towards a better or towards the worse, it has become obligations for parents to utilize the potential and channel it towards the matter blessed by God

${ }^{23}$ Ibid., 113-114.
Almighty. "O ye who believers, guard yourself and families from a fire". ${ }^{24}$

Maintaining yourself and your family from the fire is by giving lessons and good education for children and wife. Accustom them to behave in high morals and show them the way to the benefit.

Every child is born in a state of purity, then both his parents who make children good and bad. And first obtained by the child when born is her mother, a loving relationship, and it automatically gets to instruction directly from the mother. Any behavior of the mother would be shot out through a rudimentary senses, from looking at his mother when nursing, through palpation or smile and a view of the mother towards her child. Everything effects on his son into manhood. So, in this case a mother is a doctor for his son, a scholar for his son, and she was the smartest of the lecturers and teachers who will teach their children in the future.

A mother is a person who is always expected her attendance for their children. A mother can raise her children to be good as well as a mother can make them be the bad guys. The goodness or badness of children, can be influenced by whether a mother can become role models for their children or not.

Such is the glorious role of a mother, and there is no role has more rewards except the role of educating their children become children blessed by Allah and His Messenger. Because children are her source of reward and the source of goodness for her. Therefore, the sholihah women should not underestimate her so great and noble role.

${ }^{24}$ Qs. Al-Hashr: 6 
The things that need to be done as educators are:

a) To let the monotheistic teachings instilled from an early age

b) To teach children to be good at ingratitude towards Allah.

c) To educate children to be filial to parents who have struggled since pregnancy to childbirth.

d) To teach children about God commands and ways to worship Him and get used to do Shalih charity.

e) To embed love for the Prophet, the Prophet's family and alQur'an.

f) To teach to always be kind to fellow humans.

g) To teach the children the good news and the God's threat when carrying out His commands and avoid His command.

h) To educate children to be brave, relentless, disciplined warrior, patient, ground, optimistic without pessimistic.

i) Not only to teach the spiritual education of children but also to teach the physical education such as: running, swimming, archery, karate, martial arts, horse riding, use of weapons.

j) To teach general knowledge that is always associated with the values of Islam. So he did not disbelieve in their Lord, as the creator and preserver. ${ }^{25}$

This is one of the lessons why Allah and His Messenger emphasize on the religious aspects of a Muslim when choosing a mate, because the Sholihah woman is a prospective educator for children born of their marriage.

So in this Rabbani generation turning, pious women, very slick

${ }^{25}$ Ibid., 114-127. required cooperation between fathers and mothers, the fathers play a role as a leader in the household. He was the commander should be an example to his wife and son. While the mother roles as a field personnel who are directly being first "madrasah" for children.

Thus, the role of the mother in a child's education can be more dominant than the father's role. This is due to the mothers to stay more at home until the intensity of the meeting with the child certainly becomes more often. ${ }^{26}$

\section{c. Women as role models in their environment}

Woman, beside its role in the family she also has other roles in society and the State. If he is an expert in the science of religion, then it is obligatory for him to preach what she knew to the other women, to encourage and embrace them in his favor. Similarly, if she is an expert in a particular field, then he had a hand in the affair, but with restrictions that have been prescribed and of course after her obligation as housewives have been met.

She should be a role model for her family, her environment and the surrounding communities by teach good virtues to children, adolescents or -housewife mothers in the neighbourhood she lives, introducing them about the dangers of delinquency or deviation on kids going on a lot around us.

\section{CONCLUSION}

Based on the results of research and analysis have been done on the

\footnotetext{
${ }^{26}$ Abu Ihsan al-Atsari and Umm Ihsan, Print Generation Rabbani, (Jakarta: Asy- Imam Library,

Shafi'i 2017), 22-23.
} 
influence of shalihah women in turning out rabbani generation in the family environment, then it is obtained some conclusions as follows:

1) There are two divisions of the characteristics of shalihah women namely: (a) Obedience to Allah (b) And, Obedience to the husband. Women who obey Allah have characteristics including: Prioritizing love of Allah, the Messenger and jihad, more than of the earth, closing the genitals (aurat), Doing good things to both the mother and father, Mandatory studying syar'i, Aamar ma'ruf nahi munkar. While the characteristics of shalihah women who obey their husbands is: implementing the obligations to their husbands, always making husband fun and giving affection towards children, Keeping honor herself and her husband's property when the husband is not at home, not underestimating the husband provision and not opening her husband disgrace and not seeking the fault for divorce, always maintaining self-esteem, physical cleanliness and beauty as well as household cleanliness, helping her husband in maintaining the trust and educating children as good as possible to become shalih shalihah children.

2) Among the tips in the turning out the rabbani generation is: getting used children to do good things, leading children into the personality of Rasululloh saw as a role model, showing Good Exemplary, praying for the children and not cursing them, filling their free time with useful things, looking for the right time to give guidance, and telling stories to instill values and virtues in the children selves.

3) The role of shalihah women in turning out Rabbani generation in the family environment is: women as servants of God, women as mothers and women as role models in their communities.

\section{BIBLIOGRAPHY}

Atsari (al), and Umm Abu Ihsan Ihsan, Print GenerationRabbani,Jakarta: Pustaka Imam Ash-Shafi'i, 2017.

Dimas, Muhammad Rashid, 25Kiat Affect Children's Soul and Intellect, Jakarta: Rabbani Press, 2005.

Faisal, Mulyadi Sanapiyah Wasesa Guntur, Educational Research Methodology, Surabaya: National Business, 1982.

Ibn Kathir, Abu Al-Fida ', Tafsir Ibn Kathir,Jakarta: Pustaka Imam Shafi'i 2005

Rida Abu Muhammad Rashid, Characteristics and Function of WomenShalihah,Solo: Pustaka AlAlaq, 2000.

Sa' ad, Jumuah, mother Exemplaryfigures,Solo: Aqwam, 2016.

Sukardi, Educational ResearchMethodology,Jakarta: PT Bumi script, 2003.

Suwaid, Muhammad Nur Abdul Hafiz, Prophetic Parenting How Prophet Educating Children, Yogyakarta: Pro-U Media , 2010.

Thabbari (al), Ibn Jarir, TafsirAtThabbar,Egypt: al-Maktabah AtTaufiqiyah 2004

Ulwan, Abdullah Nasih, Child Education inIslam,Jakarta: Pustaka Amani 2002 